\title{
Proper, Weighty and Extremely Weighty Cause to End an Employment Contract in Finland
}

\author{
Emma-Lotta Mäkeläinen*
}

UEF Law School, University of Eastern Finland, Joensuu, Finland

\section{Sofia Toivonen**}

UEF Law School, University of Eastern Finland, Joensuu, Finland

\section{Tiina Räsänen***}

UEF Law School, University of Eastern Finland, Joensuu, Finland

\begin{abstract}
Employment relationship can be ended in many ways and under different circumstances. This article discusses the rules in Finland regarding the termination of employment contract. It analyses in outline what can be considered as a proper and weighty reason or an extremely weighty reason to end an employment contract. The Finnish Employment Contracts Act demands that there must always be a proper and weighty reason to end the employment contract. If the employer wants to end the employment contract summarily without notice, there must even be an extremely weighty reason to do that. Even though the employment legislation stipulates that there must be a legal ground to end the employment contract, the legislation does not contain any list of the acceptable grounds of termination or cancellation of the employment contract. In the legal practice and legal literature, it has been argued that the proper and weighty reason may be for example the neglect of the work obligations, competing activity and violating of the business secrets, use of intoxicants, criminal activity and inappropriate behaviour and in some cases even illness. However, the grounds for the termination or cancellation of the employment contract cannot be precisely defined because every termination and cancellation of the employment contract is unique.
\end{abstract}

Keywords: Termination, Cancellation, Employment Contract, Law, Finland .

How to Cite (chicago-16th): Mäkeläinen, Emma-Lotta. "Proper, Weighty and Extremely Weighty Cause to End an Employment Contract in Finland." Udayana Journal of Law and Culture 2, no. 1 (2018): 1-27. https://doi.org/10.24843/UJLC.2018.v02.i01.p01

DOI: https://doi.org/10.24843/UJLC.2018.v02.i01.p01

\footnotetext{
E-mail: emmama@uef.fi

** E-mail/Corresponding Author: sofia.toivonen@gmail.com

*** E-mail: tiinras@uef.fi.
} 


\section{Introduction}

\subsection{Background}

In Finland, työsopimuslaki (the Employment Contracts Act, 55/2001, TSL) regulates employment contracts. The Act considers the employee as the weaker party in an employment contract. That is why the law establishes mandatory legal minimum standards for the protection of employees. The Employment Contracts Act and työehtosopimuslaki (the Collective Agreements Act, 1946/436) are the most important sources of Finnish labour law. There are hundreds of collective agreements that determine the minimum level of wages and other terms of employment contracts in various industries. An employment contract regulates an employment relationship between an employer and an employee. In addition, companies may also have their own rules and regulations. The Labour Court issues final judgments on disputes regarding interpretation of collective agreements. ${ }^{1}$

The employment contract can end in many ways in Finland. An employment relationship may end by giving notice, cancelling the employment agreement or through the expiration of a fixed-term employment agreement. If the employment agreement is terminated by giving notice, the employment relationship ends after the notice period. If an employment agreement is cancelled, the employment relationship ends immediately. The employment contract may also be dismissed when the employee has reached the age of retirement ${ }^{2}$. Additionally, during the trial period ${ }^{3}$, the employment contract may also be cancelled with immediate effect by either party. Legislation, and if applicable, a collective agreement, as well as the employment agreement itself, set out detailed rules regarding the valid grounds for terminating an employment relationship.

According to Employment Contracts Act, the employer shall terminate a valid employment contract only with a proper and weighty reason and cancel it only with an extremely weighty reason. However, there is not a list containing the grounds for

1 On a general level, labour law can be divided into Employment Contracts Act, työehtosopimuslaki (Collective Agreements Act, 1946/436), lakiyhteistoiminnasta yrityksissä (Act on Co-operation within Undertakings, 334/2007), työterveyshuoltolaki (Occupational Health Act, 2001/1383) and työturvallisuuslaki (Occupational Safety Act, 738/2002) (including provisions regulating working time and annual holidays), and social security law. Cf. Markus Äimälä and Johan Åström and Mikko Nyyssöä. Finnish Labour Law in Practice. (Helsinki: Alma Talent Oy, 2012), 15; Aapo, Surakka. Access to Finnish Law. (Helsinki: Sanoma Pro, 2012), 188.

2 An employee's employment relationship is terminated without giving notice and without a notice period at the end of the calendar month during which the employee reaches the age of retirement, unless the employer and the employee agree to continue the employment relationship. The retirement age is 68 for those born in 1957 or earlier, 69 for those born in 1958-1961, and 70 for those born in or since 1962. The employer and the employee may agree on a fixed-term continuation of an employment relationship. (TSL 6:1a).

3 The employer and the employee may agree on a trial period of a maximum of six months starting from the beginning of the work. During the trial period, the employment contract may be cancelled by either party. The employment contract may not, however, be cancelled on discriminatory or otherwise inappropriate grounds with regard to the purpose of the trial period. (TSL 1:4) 
termination or cancellation in the Employment Contracts Act. The lack of legislative articulation of these legal grounds causes many problems in applying the Act.

\subsection{Purpose, Scope, and Method}

This article analyses in outline what can be considered as a proper and weighty reason or an extremely weighty reason to end an employment contract. This is a current topic in the Finnish legal system. Furthermore, the lack of clarity of these grounds causes many problems in the interpretation. Employment Contracts Act does not give a straight answer to the question what can be considered as a proper and weighty reason or an extremely weighty reason to end an employment contract. The legal practice and legal literature can be used in the problematic questions of interpretation when the law fails to give the sufficient answer to the question mentioned above.

It cannot be denied that the issue of freedom of movement and the membership of Finland in the European Union have an impact on the development of Labour Law in Finland. What this article offers is a lesson-learned in which Finnish legal system and its practice on termination of employment might be useful for not only European legal scholars and law practitioners, but also for a wider scope of readers over the world. ${ }^{4}$

This paper uses some Finnish legislation, including Collective Agreements Act, Employment Contracts Act, Act on Co-operation within Undertakings, Occupational Health Act, and Occupational Safety Act. Juridical analysis provided in this article very much refers to some judgments awarded by the Labour Court of Finland, the Court of Appeal, and the Supreme Court of Finland. In addition, it also cites some relevant books, journals, and reports to find the legal concept, the basis of argument, and comparative views.

\subsection{Literature Review}

There have been some scientific writings that discuss legal aspects of employment in Finland, in which most of them are carried out in a comparative approach. Markus Sädevirta, for example, provides a comparative study concerning the regulation of fixed-term employment contracts in the Framework Agreement on Fixed-Term Work in three European Union (EU) member States: Finland, France and the United Kingdom (UK). The study found that legislation restricting the use of successive fixed-term employment contracts was already in place in both Finland and France, that requires no further implementation measures, while The UK had to introduce completely

$4 \quad$ For example, constitutional and statutory protection on the right to work and earn just remuneration in Finland has ever been academically compared to the situation in Tanzania. See, Clement Mashamba, "The Promotion of Basic Employee Rights in Tanzania", African Human Rights Law Journal 7, no. 2 (2007): 478. 
new measures to implement the Directive. ${ }^{5}$ Bengt Furåker, Kristine Nergaard, Antti Saloniemi also published an article that examines patterns of lock-in among employees in the labour markets in three Nordic countries: Finland, Norway and Sweden. The concept of 'lock in' illustrates employees who have considerable difficulty in finding an equally good job with some other employer ${ }^{6}$. A comparative survey has also ever been carried out to address job protection legislation, including job security for both temporary and permanent employment contracts. ${ }^{7}$

Annika Rosin publishes some comparative legal writings that assess the protection of the rights of trainees under Finish Labour Law, particularly about the issue of their status, categorisation, traineeship contract, and wage. ${ }^{8}$ She also discusses how Finnish Labour Council practice found trainees are in a subordinate relationship with the employer, regardless of the fact that they were performing work under the traineeship contract concluded between the educational institution and the employer; and how arguments established by Finnish academic literature that arguing the work of trainees are performed in, directed and control by the educational institution, entails no employment relationship evolves because of that kind of subordination, whatever the facts that educational institution may use such work outcome. ${ }^{9}$ Recently, Rosin has finished her Ph.D thesis on the same issue. She concluded her research by arguing that as trainees work in a subordinate relationship to the employer, they should, therefore, be regarded as 'employees' and that the practice of denying the 'employee'-status of trainees is not rooted in the fundamental tests used to determine the personal scope of labour law but connected to an incorrect interpretation of labour law. ${ }^{10}$

Teemu Kautonen, et.al carried out a research that reviews empirical, conceptual and legal-policy approaches to involuntary self-employment with case study of Finland, Germany, and the UK. ${ }^{11}$ The legal aspect of this article assesses on how closely the

5 Markus Sädevirta, "Regulation of Fixed-Term Employment Contracts in the EU, France, Finland and the United Kingdom: A Comparative Analysis," International Journal of Comparative Labour Law and Industrial Relations 31, no. 2 (2015): 207-231.

6 Bengt Furåker, Kristine Nergaard, Antti Saloniemi, "Lock-in Patterns among Employees: A Nordic Comparison" International Journal of Comparative Labour Law and Industrial Relations 30, no.4 (2014): 435-458.

7 Jørgen Svalund Fafo, Antti Saloniemi, and Patrik Vulkan, "Attitudes towards Job Protection Legislation: Comparing Insiders and Outsiders in Finland, Norway and Sweden", European Journal of Industrial Relations 22, no. 4 (2016): 372-377, http:// doi/10.1177/0959680115626057

8 Annika Rosin and Merle Erikson, “A Trainee's Right to a Wage: the Estonian Situation with Comparative Insights from Slovenia, the United States of America and Finland”, European Journal of Social Law, no. 3 (2014): 190.

9 Annika Rosin and Merle Muda, "Labour Law Status of A Trainee: The Estonian Situation with Comparative Insights from Finland, France and the US", European Labour Law Journal 4, no.4(2013): 300 .

10 Annika Rosin, "Labour Law Protection of Trainees" (Ph.D Thesis, Faculty of Law, University of Turku, 2017), 46.

11 Teemu Kautonen, et.al, “Involuntary self-employment' as a Public Policy Issue: A Cross-Country European Review", International Journal of Entrepreneurial Behaviour \& Research 16, No. 2 (2010): 112. 
contractual arrangement between the self-employed worker and the principal resembles an employment relationship. ${ }^{12}$

Sebastian Sandvik wrote a thesis that investigating the economic effects of the trial periods for employment contracts and how the legislation can be designed to promote efficiency. The analysis of this academic research takes place within the framework of the Finnish legal paradigm, which in turn requires a specification of the legal and economic meanings of the trial period in Finland. ${ }^{13}$

Paula Koskinen, Maria Törnroos Hanken, and Roosa Kohvakka deliberate the issue of challenges in Finnish gender equality legislation with regards to the obligation of employers to promote gender equality. ${ }^{14}$ In this paper, authors conceive institutionalised undervaluation' to measure how the undervaluation of women's work is embedded in the formal structure of wage determination such as collective agreements. ${ }^{15}$

\section{Result and Discussion}

\subsection{Termination of an Employment Contract}

\subsubsection{The Concept of Termination}

According to the Employment Contracts Act Chapter 7 Section 1, the employer shall not terminate an indefinitely valid employment; proper and weighty reason. Grounds for terminating the employment contract can be divided into two categories: grounds relating the employee's person (individual) and financial and productionrelated grounds (collective). According to the Employment Contracts Act 7:3.1 the financial and production-related grounds for termination refer to cases in which the employer may terminate the employment contract if the work offered has diminished substantially and permanently for financial or production-related reasons or for reasons arising from the reorganization of the employer's operations.

Both the employee and the employer can give notice on the employment contract. However, only the employer must have legal grounds to do so. The employee does not have to present justification for giving notice to end the employment contract, but must follow the notice periods. ${ }^{16}$ Employment Contracts Act 6:2-3 determine that the notice period ranges from 14 days to six months, depending on the length of the employment relationship. The notice period starts to elapse after notice is given, and after its expiry the employment relationship ends. The right to give a notice relates to employment contracts made for the time being. Fixed-term employment contracts

\footnotetext{
12 Ibid, 116.

13 Sebastian Sandvik, "The Economic and Social Effects of Trial Periods for Employment Contracts"(Master Thesis, Faculty of Law University of Helsinki, 2016), 1 .

14 Paula Koskinen, Maria Törnroos Hanken, and Roosa Kohvakka, "The Institutionalised Undervaluation of Women's Work: The Case of Local Government Sector Collective Agreements”, Work, Employment and Society (June 2017): 5. http:// doi.org/ 10.1177/0950017017711100

15 Ibid, 14.

16 Markus Äimälä and Johan Åström and Mikko Nyyssölä, Op.Cit, 155.
} 
cannot be terminated upon notice, unless this has been specifically agreed when entering into the contract. ${ }^{17}$ During the notice period, the employment relationship continues as normal, unless the contracting parties agree otherwise. ${ }^{18}$

In accordance with Employment Contracts Act Chapter 6 Section 4, if the employer terminates the employment relationship without observing the notice period, he shall pay the employee full pay for a period equivalent to the notice period as compensation. If the employee does not observe his notice period, he is bound by law to pay compensation to the employer. ${ }^{19}$

If the termination is deemed unlawful by a competent court, the employer will be ordered to pay compensation to the employee. According to Employment Contract Act Chapter 12 Section 2, the exclusive compensation must be equivalent to the pay due owed for a minimum of three months or a maximum of 24 months. Nevertheless, the maximum compensation is 30 month's salary for employees enjoying special protection against dismissal. Depending on the reason for terminating the employment relationship, the following factors must be taken into account in determining the amount of compensation: the estimated time without employment and estimated loss of earnings, the remaining period of a fixed-term employment contract, the duration of the employment relationship, the employee's age and chances of finding employment corresponding to his or her vocation or education and training, the employer's procedure in terminating the contract, any desire for termination originating in the employee, the general circumstances of the employee and the employer, and other comparable matters. When determining the amount of compensation, any compensation already awarded for the same act of dismissal by the virtue of yhdenvertaisuuslaki (the Non-discrimination Act, $1331 / 2014)^{20}$, must be taken into account.

\subsubsection{Improper Causes for Termination of the Employment Contract}

Finnish Employment Contracts Act does not contain any list of the grounds that may be considered proper and weighty reasons for the termination of the employment contract. However, the act contains several grounds of termination that cannot be regarded as proper and weighty reasons. According to Employment Contracts Act Chapter 7 Section 2, at least the following cannot be regarded as

17 Ibid; Markus Äimälä and Mika Kärkkäinen, Työsopimuslaki (Helsinki: Alma Talent Oy, 2017), 381; Harri Hietala and Tapani Kahri and Martti Kairinen, Työsopimuslaki käytännössä (Helsinki: Alma Talent Oy, 2016), 339.

18 Ibid, 156; Markus Äimälä and Mika Kärkkäinen, Op.Cit, 383.

19 Ibid, 158.

20 The provision on minimum compensation cannot be applied to termination due exclusively to changes in the employer's operating conditions (production-related or financial reasons, or termination in connection with a reorganization procedure), or in cases where the employment contract has been cancelled on the basis of the trial period or with inadequate cancellation grounds while nevertheless fuelling the grounds for termination. Cf. Ministry of Employment and the Economy, "Employment Contracts Act. The position of employers and employees under the Employment Contracts Act", 50. 
proper and weighty reasons:

1. illness, disability or accident affecting the employee, unless working capacity is substantially reduced thereby for such a long term as to render it unreasonable to require that the employer continues the contractual relationship;

2. participation of the employee in industrial action arranged by an employee organization or in accordance with the Collective Agreements Act;

3. the employee's political, religious or other opinions or participation in social activity or associations;

4. the employee's resort to means use of legal protections available under the law available to employees.

In addition to the above-mentioned grounds, there are also special rules for the assignment of an enterprise, bankruptcy, the death of an employer and the restructuring of enterprises. There are also special rules concerning an employee's pregnancy, shop stewards and other elected representatives.

According to Employment Contracts Act Chapter 7 Section 9 pregnancy is not a legal ground for dismissal. If a pregnant woman or a person on family leave is dismissed, the legal presumption is that the employer has used the pregnancy or family leave as the real cause for the dismissal. The employer must prove that there is an acceptable legal cause other than the pregnancy, otherwise the dismissal is unlawful. ${ }^{21}$

\subsection{Proper and Weighty Causes for the Termination of an Employment Contract}

\subsubsection{Proper and Weighty Reasons in General}

According to the Finnish Employment Contracts Act, the employer must have a proper and weighty reason to give a notice of termination of the employment contract. When considering whether the individual or collective cause is a proper and weighty cause to terminate the employment contract, the general provision must be taken into account.

According to Employment Contracts Act (TSL 7:2.1), serious breach or neglect of obligations arising from the employment contract or the law and having essential impact on the employment relationship as well as such essential changes in the conditions necessary for working related to the employee's person as render the employee no more able to cope with his or her work duties can be considered a proper and weighty reason for termination arising from the employee or related to the employee's person. ${ }^{22}$

\footnotetext{
21 Aapo Surakka, Op.Cit, 196-197.

22 TSL $7: 2.1$.
} 
The proper and weighty reason, inter alia, means that the reason for the termination cannot be discriminatory or against the employer's responsibility to treat all employees equally, unless deviating from this is justified in view of the duties and position of the employees. ${ }^{23}$ A proper and weighty reason also means that the grounds for termination cannot be in breach of the duty of loyalty between the employee and employer. ${ }^{24}$

When grounds for the termination of an employment contract are under consideration, the overall circumstances and all the relevant facts of the case in question must be taken into account. The importance of the overall assessment is emphasized especially in difficult borderline cases. ${ }^{25}$

\subsubsection{Proper and Weighty Causes for the Termination of an Employment Contract}

\subsubsection{Proper and Weighty Reasons in General}

According to the Employment Contracts Act Chapter 3 Section 1, the employees shall perform their work carefully, observing the instructions concerning their work performance issued by the employer, within their competence. In their activities, employees shall avoid everything that conflicts with the actions reasonably required of employees in their position.

An employee's duty to work can also be considered to be part of the employment contract. ${ }^{26}$ If the employee breaches his or her duty to work, he also breaches the contractual obligations that arise from the employment contract. ${ }^{27}$ Instructions given by the employer cannot be considered as such essential obligations that the breach of these obligations would justify the termination of the employment. The essential obligations of the employment contract vary according to the nature of the employment relationship. Furthermore, termination of the contract of employment requires that the employee has breached his or her obligations in a serious manner. ${ }^{28}$

One of the most common grounds that leads to the termination of employment contracts is the neglect of work obligations which can appear as a single omission of a duty or defective fulfilment of duties, carelessness or passivity i.e. inefficiency. The situations where the neglect of duty to work appears can be divided into two categories,

23 Government proposal to Parliament "HE 157/2000 vp: Government proposal for the contracts of employment act." 96.Cf. The Supreme Court of Finland (KKO) 2016:15.

24 'The duty of loyalty' means a duty of the employment contracting parties to reasonably consider each other's interests and expectations without unreasonably risking their own. Cf. KM 1969, 31.

25 Government proposal to Parliament "HE 157/2000, Loc.Cit.

26 Cf. Ollila DL 6/2017, 906.

27 Government proposal to Parliament "HE 157/2000, Op.Cit. 97.

28 The Supreme Court of Finland (KKO) 2016:62, 8. 
based on whether the neglect of duty is intentional or unintentional. ${ }^{29}$ Additionally, taking care of personal matters (for example using an employer's phone for personal calls) during work time can also be considered as neglecting the duty to work. The bigger the neglect of work obligations is and the more it causes damage to the employer, the more likely the omission will be considered a proper and weighty cause to terminate the contract of employment. ${ }^{30}$

Regarding this matter, the Supreme Court of Finland has issued a judgment:

The employee had been using the employer's radio phone for his own personal matters for four and a half months, altogether for 13 hours. During the phone calls, the radio phone couldn't have been used normally. Due to his behaviour, the employee had caused damage to his employer, such as undue phone expenses and inhibiting the normal purpose for use. The inhibition of the use also led to a loss of income. The employer had a proper and weighty cause to terminate the contract of employment but not an extremely weighty cause to cancel the contract with immediate effects. ${ }^{31}$

\subsubsection{Unauthorized Absence}

The employee's primary obligation is to work, and being absent from work without a proper reason is a dereliction of this obligation. Hence, being absent from work without a proper reason may result in the termination of the employment contract. Absences that may result in the termination of the employment relationship include being late, leaving early or being absent the whole day. ${ }^{32}$

Many professions require punctuality and even minor tardiness may constitute grounds for dismissal. The employer may require punctuality in all professions. If punctuality has been stressed, deviating from the set working hours may be considered substantial dereliction. How long or how often the repeated, unauthorized absence entitles the employer to terminate or cancel the employment contract depends on overall assessment which needs to be done case-by-case. Generally, one short absence does not entitle the employer to end the employment contract. ${ }^{33}$

The following two case laws before the Labour Court (TT) of Finland may describe this concern. The first case is regarding a train waitress who had been found sleeping in a sleeping cabin after a break and for that reason there was no breakfast service in the train. Before this incident, the waitress had been given two written warnings

29 Seppo Koskinen "Työsuhdeturva". Edilex 2013, p. 29; Seppo Koskinen and Kimmo Nieminen and Mika Valkonen, Työsuhteen päättäminen (Lithuania: Talentum Media Oy, 2012), 767.

30 Seppo Koskinen and Kimmo Nieminen and Mika Valkonen, Op.Cit, 778.

31 The Supreme Court of Finland (KKO) 1991:26.

32 Markus Äimälä and Mika Kärkkäinen, Op Cit, 491; Markus Äimälä and Johan Åström and Mikko Nyyssölä, Op.Cit, 161.

33 Ibid. 
in the previous six months because of her neglect of her duty to work. The employer had had a proper and weighty cause to terminate the contract of employment. ${ }^{34}$

The second case is about different situation. Initially the employee had been scolded, and then six months later he had been given a warning due to inappropriate behaviour. Two weeks after the warning had been given, the employee left the workplace without permission during working hours and his employment contract had been terminated after this incident. The employee's behaviour was a proof of remissness towards his work obligations. The employer had had a proper and weighty cause to terminate the employment contract. ${ }^{35}$

On the other hand, if the employer has tacitly accepted longer lunch breaks etc., the employer cannot dismiss an individual worker who follows the common practice. If the employee is absent without presenting an acceptable reason for his conduct, the employment relationship can be terminated by notice or even summarily, depending on the severity of the case. In practice, the termination on grounds of absenteeism requires a prior warning to the employee. Only if the dereliction is of such severity that the employer cannot reasonably be expected to continue the employment relationship, will it be established that a prior warning to the employee is not necessary. ${ }^{36}$

The Supreme Court of Finland (KKO) 1980 II 117: The employee had left the workplace without permission, but this alone wasn't regarded as a proper and weighty cause which would entitle the employer to terminate the employment contract. However, the employee had been given a written warning because of a similar behaviour three months earlier. When taking the overall circumstances into account, the employer had a proper and weighty reason to terminate the employment contract.

Labour Court of Finland (TT) 1987-34: An unauthorized absence which lasted for one day was not regarded as a proper and weighty cause to terminate the employment contract. The employer was ordered to pay compensation to the employee on the grounds of unfounded termination of the employment contract. However, the size of the compensation was reduced due to employee's behaviour.

\subsubsection{Negligence}

Employees must perform their work carefully, observing any instructions concerning performance issued by the employer within its competence (TSL 3:1). Carelessness is the neglect of this obligation and may entitle the employer to terminate the employment relationship. ${ }^{37}$ Negligence means the dereliction of work

\footnotetext{
34 Labour Court of Finland (TT) 2004-7.

35 Labour Court of Finland (TT) 2004-63.

36 Markus Äimälä and Johan Åström and Mikko Nyyssölä, Op.Cit, 161.

37 Ibid, 162.
} 
obligations is not intentional. In other words, negligence can be understood as the employee's approach towards his or her work obligations. However, slight negligence is not regarded as an adequate reason to terminate the employment contract. ${ }^{38}$ In contrast if the negligence is manifest or clearly apparent, it can entitle the employer to terminate the employment contract. ${ }^{39}$ Negligence is normally assessed in relation to other employees' average work performance. ${ }^{40}$

The severity of the negligence can be assessed by taking into account factors such as the repetition of acts of dereliction, the special characteristics of the work duties, work circumstances, the effects of any reprehensible actions and the employee's position in the organisation. ${ }^{41}$ Additionally, termination usually requires a preceding warning. ${ }^{42}$

\subsubsection{Unprofessionalism}

The concept of professionalism is wide and ambiguous. The core of professionalism is that the employee is able to carry out the concrete duties that have been assigned to him. ${ }^{43}$ Necessary ability might also require management of tools, particular work practices, management of materials, information and occupational safety requirements. Additionally, personal characteristics, such as an ability to cooperate, can be seen as the part of the requirement of professionalism. ${ }^{44}$

According to the court decisions, in some cases, performing work without sufficient skill may constitute the grounds for termination. The employee can be terminated, if he is constantly unable to meet the set objectives. ${ }^{45}$ However, an unprofessional employee should firstly be transferred to another job that is more suitable for him. ${ }^{46}$ Nevertheless, if the employee disagrees concerning the inadequacy of his professional qualifications and takes the matter before a decision of the court, the employer should have evidence proving employee's unprofessionalism. ${ }^{47}$

38 Seppo Koskinen and Kimmo Nieminen and Mika Valkonen, Op.Cit, 88.

39 Kari-Pekka Tiitinen and Tarja Kröger, Työsopimusoikeus (Helsinki: Talentum 2012), 514; Seppo Koskinen and Kimmo Nieminen and Mika Valkonen, Loc.Cit. Cf. The Court of Appeal of Vaasa (VHO) 24.3.2017 S 16/320, The Labor Court of Finland (TT) 2005-11; 2005-65; 1992-37.

40 Seppo Koskinen and Kimmo Nieminen and Mika Valkonen, Loc. Cit.

41 Ibid.

42 Ibid, 77.

43 Markus Äimälä and Mika Kärkkäinen, Op.Cit, 498.

44 Ibid.

45 The employer has the responsibility to establish the competency of the job applicant to do the work. The employer should establish that the employee is a skilled worker by examining his testimonials and education reports and by interviewing him. Markus Äimälä and Johan Åström and Mikko Nyyssölä, Op.Cit, 162. Seppo Koskinen. "Harhaanjohtaminen työsopimusta tehtäessä". Edilex, (2005): 5; Aki Ollila. "Työnhakijan Tiedonantovelvollisuus" Defensor Legis, no. 1 (2017): 20; The Court of Appeal of Turku (THO) 11.6.2003 S02/2032. Markus Äimälä and Mika Kärkkäinen, Loc.Cit.

46 Markus Äimälä and Mika Kärkkäinen, Op.Cit, 499.

47 Martti Kairinen et al. Työoikeus (Juva: WSOYpro, 2006), 72; Cf. also Kari-Pekka Tiitinen and Tarja Kröger, Op.Cit, 339 - 400. Cf. The Labor Court of Finland (TT) 1992-99. 


\subsubsection{Refusal to Work}

Refusal to work means that the employee refuses to complete certain duties or work at certain times and/or in certain places. The employee has the responsibility to complete the duties that arise from the employment contract. ${ }^{48}$ That means that the employee is not entitled to refuse to complete the duties he is required to perform under his employment contract and refusal usually constitutes the grounds for a dismissal. Dismissing the employee may require that the employee has been given a warning about such conduct and its consequences. The employment relationship can be terminated immediately after the warning if the employee states that he is not going to perform the tasks directed to him. ${ }^{49}$

The employee is required to perform work described in the employment contract or in the collective agreement. ${ }^{50}$ The tasks can be described in detail or more generally. For instance, it can be agreed that the employee performs tasks as directed to him by the employer. The tasks the employee performs in reality influence the notion of the agreed tasks. If the tasks vary a great deal and the job description does not preclude certain tasks, the employer has extensive rights to order the employee to perform a wide variety of tasks. ${ }^{51}$

The Supreme Court of Finland (KKO 2010:60): The employee's main duties included cleaning the gym. Later, the employer had unilaterally assigned new duties to the employee that included cleaning in another building. The employee refused to complete the unilaterally assigned duties and the employment contract was terminated. Because the new duties changed the terms of the employment contract significantly, the employer had no right to assign extra work under his power of supervision of work. Thus, the employer had no proper cause to end the employment contract based on the refusal.

If the employee has a reasonable ground for refusal, for example if the duties could expose the employee to danger, the employer has no right to end the employment. ${ }^{52}$ The ground for refusal can also be something other than a safety reason. Another reasonable ground for refusal to complete the assigned duties is if the employer fails to pay the salary or that the new duties require the employee's permission. ${ }^{53}$ However, the employer might be entitled to not to pay the salary for the time period where the employee has not had a sufficient ground for the refusal to work. This right can arise even though the employer does not have a sufficient ground to end the employment contract. ${ }^{54}$

\footnotetext{
48 Seppo Koskinen and Kimmo Nieminen and Mika Valkonen,Op.Cit, 80.

49 Markus Äimälä and Johan Åström and Mikko Nyyssölä, Op.Cit,162.

50 Ibid; Seppo Koskinen and Kimmo Nieminen and Mika Valkonen, Op.Cit, 81.

51 Ibid; Kari-Pekka Tiitinen and Tarja Kröger, Op.Cit, 506.

52 Seppo Koskinen and Kimmo Nieminen and Mika Valkonen, Op.Cit, 83.

53 Ibid, 84.

54 Cf. The Supreme Court of Finland (KKO) 1983 II 144.
} 


\subsubsection{Conduct Contrary to Instructions}

According to the Employment Contracts Act Chapter 3 Section 1, the employee must perform his work by observing the instructions concerning performance issued by the employer within its competence. The employee neglects the instructions if he acts against the specific instructions or completes the duties incorrectly. ${ }^{55}$

According to the court decisions and legal literature, acting contrary to the employer's directions may constitute grounds for dismissal. The situation is evaluated with reference to the clarity of the employer's directions, the seriousness of the employee's contrary conduct, the established or standard practices in the organisation, the repetitiveness of the employee's action and whether the employee has received a warning for similar conduct before, etc. ${ }^{56}$ If the neglect or contrary conduct is minimal, there are no grounds for termination of the employment contract. ${ }^{57}$

If there has already been a long period of employment and the employee has not received any warnings and the negligence or contrary conduct is slight, there might not be a proper and weighty reason to terminate the employment contract. In situations where the employee acts against the instructions, it is normally required that a warning has been given and that the employee continues his actions that are contrary to those instructions before termination of the employment is possible. If the employee continues the actions against the instructions after the warning has been given, it is more likely the employer is entitled to end the employment. ${ }^{58}$

\subsubsection{Competing Activity and Business Secrets}

\subsubsection{Competing Activity}

According to Employment Contracts Act Chapter 3 Section 3, the employees shall not work for another party (ie company) or engage in such activity that would, taking the nature of the work and the individual employee's position into account, cause manifest harm to their employer as a competing activity contrary to fair employment practices. During the term of employment, employees shall not embark on any action to prepare for competing activities which might be deemed unacceptable.

Employees actions are regarded as competitive if the actions are obviously against the established good practice and cause harm to the employer. For example, establishing a new company is regarded as a competing action. All competing activities of a self-employed entrepreneur are also prohibited during the employment ${ }^{59}$ and

55 Seppo Koskinen and Kimmo Nieminen and Mika Valkonen, 85.

56 Markus Äimälä and Johan Åström and Mikko Nyyssölä, Op.Cit, 162.

57 Seppo Koskinen, Kimmo Nieminen and Mika Valkonen, Op.Cit, 85-86.

58 Ibid, 86.

59 Harri Hietala and Keijo Kaivanto, Työsopimus ja johtajasopimus (Helsinki: Alma Talent Oy, 2017), 84. 
this prohibition lasts the entire employment. ${ }^{60}$ However, the employee may work in several employment relationships simultaneously, but must not engage in any activity that competes with his employer while their employment relationship lasts. ${ }^{61}$ The breach of this prohibition might lead to termination or cancellation of the employment contract. ${ }^{62}$

The employee has an obligation to act loyally towards the employer, i.e. he must avoid actions that conflict with the benefit of the employer. Because the damage to the employer must be obvious, merely the chance that the actions might harm the employer does not make the actions unlawful. Whether the actions are against good practice is considered case-by-case. ${ }^{63}$ On the other hand, it is not required that the employer has actually experienced damage however, there must be a concrete danger of damage. ${ }^{64}$ In a case law, the Supreme court considered that when the accountant started as a sleeping partner in another accounting company without telling to the employer, the actions were regarded as competing actions against good practice. $^{65}$

It is clear that the employee is not entitled to use his working hours and the employer's implements for making preparations for his own entrepreneurship. Gaining customers, bidding for contracts and recruiting employees maybe considered as competing activities, even if no contracts have been made. ${ }^{66}$

In the legal literature, it has been argued that the employees in high positions can be held to more extensive obligations of loyalty, and their right to perform competing activities can be more restricted. The extent and nature of the employer's business must also be taken into account. Also, Employment Contracts Act argued that the individual employee's position may have influence.

The employee may be liable for the damage that his competing activity has caused to the employer. ${ }^{67}$ Also, as determined by the Employment Contracts Act (TSL 3:3.3), an outside employer who hires an employee, knowing that the employee breaches his existing employment agreement with another company by virtue of signing a new employment agreement, maybe liable for damage to the first employer. ${ }^{68}$

\footnotetext{
60 Markus Äimälä and Mika Kärkkäinen, Op.Cit, 248.

61 Markus Äimälä and Johan Åström and Mikko Nyyssölä, Op.Cit, 163; Government proposal to Parliament "HE 157/2000, Op.Cit. 79.

62 Government proposal to Parliament "HE 157/2000, Op.Cit, 96. s. 80; The Supreme Court of Finland (KKO) 1995:47 and 1990:37.

63 Ibid. 79.

64 Markus Äimälä and Mika Kärkkäinen, Op.Cit, 249.

65 The Supreme Court of Finland (KKO) 1984 II 131:

66 Markus Äimälä and Johan Åström and Mikko Nyyssölä, Loc.Cit; Harri Hietala and Keijo Kaivanto, Loc. Cit, 84.

67 Ministry of Employment and the Economy, Op.Cit, 24; Markus Äimälä and Mika Kärkkäinen, Loc. Cit.

68 Cf. Government proposal to Parliament "HE 157/2000, Op.Cit, 7.
} 


\subsubsection{Business and Trade Secrets}

Under Employment Contracts Act Chapter 3 Section 4, during the term of employment, the employee may neither utilize nor divulge to third parties the employer's trade or business secrets. If the employee has obtained such information unlawfully, the prohibition continues after termination of the employment relationship. The liability for any loss incurred by the employer is extended not only to the employee divulging confidential information but also to the recipient of this information, if the latter knew or should have known that the employee had acted unlawfully in disclosing the information.

Rikoslaki (39/1889, Criminal Code of Finland, RL) chapter 30 section 5 also includes provisions concerning violations of business secrets. The provision also covers the unlawful disclosure and utilization of business secrets. A person who, in order to obtain financial benefit for himself or herself or another, or to injure another, unlawfully discloses the business secret of another or unlawfully utilises such a business secret, shall be punished (RL 30:5). The actions must be carried out intentionally whereas according to Employment Contracts Act, negligent actions might lead to a punishment. In addition to Criminal Code of Finland and Employment Contracts Act, laki sopimattomasta menettelystä elinkeinotoiminnassa (Unfair Business Practices Act, 1061/1978) includes regulation concerning the business and trade secrets.

The Acts do not include the specific content of business and trade secrets. According to the court decisions and legal literature, the confidential business and trade information may include information such as working methods, computer programs, output, formulas and customer registers. In determining the confidentiality of such information, the essential criterion is that the employer needs to keep the information confidential and that divulging it would cause harm to the enterprise. ${ }^{69}$

In the government's proposal concerning Employment Contracts Act, the section has been clarified that the prohibition on divulging confidential business and trade information applies throughout the employment relationship. ${ }^{70}$ As long as the information is received lawfully, for instance during the work, the prohibition no longer applies after the end of the employment relationship, unless the employer and the employee make a non-disclosure agreement for the time after the termination of the employment relationship. ${ }^{71}$ However, if the employee, during the course of the employment relationship, has acquired or received confidential business and trade information unlawfully, the prohibition on divulging or utilizing such informa-

69 Government proposal to Parliament "HE 157/2000, Op.Cit, 80; Ministry of Employment and the Economy, Op.Cit, 24-25.

70 Ibid, 81; Ministry of Employment and the Economy, Op.Cit, 25; Report of Committee of Employment Contract act" Työsopimuslakikomitean mietintö 1969:A25”, 32.

71 Ministry of Employment and the Economy, Loc.Cit. 
tion remains valid even when the employment relationship ends, and will continue in force until the information can no longer be objectively regarded as confidential business and trade information from the point of view of the employer. ${ }^{72}$

If the employee breaches the prohibition to utilize and divulge the business and trade secrets, it normally entitles the employer to terminate the employment agreement. An intentional breach might also justify the cancellation of the employment contract but if the action has been unintentional, a warning could be a sufficient sanction. ${ }^{73}$

\subsubsection{Use of intoxicants}

The abuse of intoxicants is one the most common grounds of employment termination. ${ }^{74}$ According to the court decisions and legal literature, if an employee is intoxicated at work or neglects his duties, the employer may be entitled to cancellation the employee's employment agreement. ${ }^{75}$ If the employer in entitled to cancellation the contract, he is naturally also entitled to terminate the contract of employment because cancellation is more forceful action than termination. In addition to alcohol, drugs are also considered intoxicants. ${ }^{76}$ Substance use often leads to other breaches, like unauthorized absences. ${ }^{77}$

However, in the legal literature, it has been argued that the employer should consider referring an employee with substance addiction to therapy, but this is not a formal requirement for terminating the employment relationship. On the other hand, if the employee is referred to therapy and the problems continue, grounds for dismissal exist. ${ }^{78}$

\subsubsection{Criminal Activity and Inappropriate Behaviour}

If an employee commits a criminal offence towards the employer or coworker or the criminal activity occurred in the workplace, the employer usually has grounds for terminating the employment relationship. ${ }^{79}$ Even minor offences may entitle the employer to terminate the employment relationship. In the court decisions, activities

72 Government proposal to Parliament "HE 157/2000, Op.Cit, 81; Markus Äimälä and Mika Kärkkäinen, Op.Cit, 262.

73 Markus Äimälä and Mika Kärkkäinen, Op.Cit, 534.

74 Ibid, 508.

75 Government proposal to Parliament "HE 157/2000, Op.Cit, 109.

76 Markus Äimälä and Mika Kärkkäinen, Loc.Cit. In the earlier Employment Contracts Act, the use of intoxicants or appearing intoxicated at the workplace were listed as grounds for summary termination of the employment relationship. Although the new Act contains no explicit reference to such conduct, the rule is still valid. The use of intoxicants usually entitles the employer to terminate the employment relationship either with or without notice. Cf. Markus Äimälä and Johan Åström and Mikko Nyyssölä, Loc. Cit.

77 Markus Äimälä and Mika Kärkkäinen, Op.Cit, 509.

78 Markus Äimälä and Johan Åström and MikkoNyyssölä, Op.Cit, 164; Markus Äimälä and Mika Kärkkäinen Op.Cit, 511-512.

79 Ibid; Markus Äimälä and Mika Kärkkäinen, Op.Cit, 164, 524; Seppo Koskinen and Kimmo Nieminen and Mika Valkonen, Op.Cit, 146. 
such as pilferage, embezzlement and forgery have been considered to be grounds for termination, irrespective of the pecuniary advantages gained by the employee. The gravity of the crime can be highly relevant when choosing between summary termination and cancellation of the employment contract. ${ }^{80}$

However, if the offence has occurred outside work, the evaluation is not as straightforward. In the court decision, it has been argued that factors such as who the victim is and to what extent the offence is connected with the employee's duties must be taken into account. ${ }^{81}$ Ordinarily in these instances there is not a proper cause to terminate the employment contract. If the offence is serious and might lead to an unconditional sentence of imprisonment, the employer is normally entitled to end the employment. ${ }^{82}$

In addition to criminal offences, improper behaviour can be a proper and weighty cause to terminate the employment contract. Improper behaviour may arise in many ways. The gravest cases are improper behaviour amounting to harassment. ${ }^{83}$ The more senior the positions of the employees, the more blameless conduct can be required from them, both within and outside the workplace. ${ }^{84}$

\subsubsection{Illness}

Under Employment Contracts Act Chapter 7 Section 2(1), an illness, disability or accident affecting the employee cannot be regarded as a proper and weighty ground to be used for terminating an employment relationship, unless the employee's working capacity is substantially reduced thereby for such a long term as to render it unreasonable to require that the employer continue the contractual relationship.

The employee's working ability must be evaluated based on the demands his work sets for him, whereby it is evaluated whether the employee meets the requirements of the work or not. ${ }^{85}$ Under Employment Contracts Act the grounds for the termination exist if the employee's working capacity is reduced substantially and for a long time. ${ }^{86}$ When considering the permanence of the reduced working capacity, the length of the illness before the termination and prediction of the forthcoming length of the illness must be taken into account. ${ }^{87}$ In the court decisions, a one-year period

\footnotetext{
80 Ibid

81 Markus Äimälä and Mika Kärkkäinen, Op.Cit, 524.

82 Ibid, 525.

83 Ibid, 527.

84 Ibid, 528.

85 Government proposal to Parliament "HE 157/2000 Op.Cit. 98; Seppo Koskinen and Kimmo Nieminen and Mika Valkonen, Op.Cit, 107-108. Cf. The Labour Court of Finland (TT) 2003-97.

86 Ibid; Seppo Koskinen and Kimmo Nieminen and Mika Valkonen, Op.Cit, 107; Leena Alapuranen et.al, "Työkyvytön?", Edilex 2008, 223.

87 Seppo Koskinen and Kimmo Nieminen and Mika Valkonen, Op.Cit, 108.
} 
has been used to establish permanence. ${ }^{88}$ Thus, the incapacity to work does not have to be permanent. Doctor's statements weigh heavily and are very important when evaluating the effect of an illness or injury to the working ability as well as the possibilities of recovery. ${ }^{89}$

Labour Court (TT) 1985-62: Illness that continued for ten months was regarded as permanent.

Labour Court (TT) 2002-47: The employee had been on sick leave for fifteen months because of depression. The court considered that the illness is significant and permanent.

The Supreme Court of Finland (KKO) 1991:2: Even though the waiter contracted HIV, his capacity to work was not reduced due to the illness.

However, prior to any action for termination the employer must consider whether there is an alternative solution such as reassigning the employee to other tasks. ${ }^{90}$

\subsubsection{Special Job Security}

As mentioned above, there are some cases in which the employee has special job security. This means that he cannot be given notice on the usual grounds. Under Employment Contracts Act Chapter 7 Section 9 pregnant employees and employees using their rights to maternity, special maternity, paternity, parental or child-care leave have special job security. This means that the employer must not terminate an employment contract on the basis of the employee's pregnancy or because the employee is exercising his or her right to family leave. On request, the employee must present the employer with proof of pregnancy. However, a pregnant employee can be dismissed on lawful grounds. ${ }^{91}$ According to Employment Contracts Act (TSL $7: 9.2)$, if the employer dismisses a pregnant employee, the dismissal is deemed to be due to the pregnancy unless the employer can show that it is due to some other reason. As a result, the employer has an enhanced burden of proof when dismissing a pregnant employee.

Under Employment Contracts Act Chapter 7 Section 9(1-2), the employee cannot be dismissed on grounds of using his or her right to family leave. Again, the employer has the enhanced burden of proof: the dismissal is considered to result from the use of family leave, unless the employer can prove that it results from some other reason.

88 Ibid; Markus Äimälä and Mika Kärkkäinen, Op.Cit, 511. Cf. The Labour Court of Finland (TT) 1984-56. Leena Alapuranen, Op.Cit, 230.

89 Markus Äimälä and Mika Kärkkäinen, Loc.Cit.

90 Markus Äimälä and Mika Kärkkäinen, Op.Cit, 517-518.

91 Markus Äimälä and Johan Åström and Mikko Nyyssölä, Op.Cit, 167. 
Under laki maanpuolustusvelvollisuutta täyttävän työ ja virkasuhteen jatkumisesta (Act on the Continuation of Contractual and Public-Service Employment Relationships of People Fulfilling Their National Defence Obligation, 305/2009) Section 3, the employment relationship cannot be terminated because the employee carries out military or non-military service. Further, the employment contract cannot be terminated during the service. Employees, who have performed military or non-military service, also have special job security after they have returned to work. Such employees may not be dismissed upon notice within three months from the day of return, unless the employer has given a prior notification of the termination at least two months before the day when the employment relationship ends. ${ }^{92}$

Employees' representatives also have protection against being given a notice (TSL 7:10). In Finland, representatives are either shop stewards or elected representatives. In this context, a shop steward means a representative who has been chosen on the grounds of a collective agreement. The employees who don't have a shop steward can elect a representative amongst themselves. Also, some other employees' representatives have similar protection against being given notice as the shop stewards and elected representatives. These are, inter alia, industrial safety delegates, co-operation representatives (regulated in the Act on Co-operation within Undertakings) and a representative whose position is based on laki henkilöstön edustuksesta yritysten hallinnossa (Act on Personnel Representation in the Administration of Undertakings, $725 / 1990)$. Their special protection is not directly based on Employment Contracts Act but on protection provisions regulated in other acts. ${ }^{93}$

According to Employment Contracts Act Chapter 7 Section 2(3) employees who have neglected their duties arising from the employment relationship or committed a breach thereof shall not be given a notice of termination, however, before they have been warned and given a chance to amend their conduct. That means the employer has no legal right to terminate an employment contract on individual grounds before it has issued a notice to the employee. The purpose of the notice is to give the employee a possibility to amend his conduct. ${ }^{94}$ In the case of termination, the issuing of a warning to the employee or the omission of a warning is significant when considering whether the ground for termination is proper and weighty. ${ }^{95}$

However, according to Employment Contracts Act Chapter 7 Section 2(5), there is no need for warning if the reason for giving notice is such a grave breach related to the employment relationship as to render it unreasonable to require that the employer continue the contractual relationship.

\footnotetext{
92 Ibid, 168.

93 Markus Äimälä and Mika Kärkkäinen, Op.Cit, 582.

94 Government proposal to Parliament "HE 157/2000, Op.Cit, 101. Cf. Seppo Koskinen, "Velvollisuus antaa varoitus työsopimuksen irtisanomisen edellytyksenä". Edilex, 1017.

95 Seppo Koskinen and Kimmo Nieminen and Mika Valkonen, Työsuhteen päättäminen (Lithuania:
} Talentum Media Oy, 2012), 63. Cf. The Labor Court of Finland (TT) 2005-1; The Court of Appeal of Helsinki (HHO) 7.1.2004 S 02/2329; The Court of Appeal of Turku (THO)11.6.2003 S 02/2032.1 
Furthermore, before the employer terminates an employment contract, the employer shall provide the employee with an opportunity to be heard concerning the grounds for the termination, in addition to which the employer shall find out whether it is possible to avoid giving notice by placing the employee in other work (TSL 7:2.4). However, this is not required if the reason for giving notice is such a grave breach related to the employment relationship as to render it unreasonable to require that the employer continue the contractual relationship (TSL 7:2.5). In these situations, the employer can cancel the employment relationship to end immediately.

\subsection{Cancellation of Employment Contract}

\subsubsection{The Concept of Cancellation}

An employment agreement binds both parties. Terminating the contract before its ordinary date of expiration is legally possible if the other party accepts it. ${ }^{96}$ Another possibility is immediate cancellation of the employment relationship, but according to the Employment Contracts Act Chapter 8 Section 1 "the employer is only upon an extremely weighty cause entitled to cancel an employment contract with an immediate effect regardless of the applicable period of notice or the duration of the employment contract." This means that the extremely weighty cause is a cause that may be deemed to exist in case when the employee commits a breach against, or neglects duties based on the employment contract or the law, and having an essential impact on the employment relationship in such a serious manner as to render it unreasonable to expect that the employer should continue the contractual relationship even for the period of notice. ${ }^{97}$

Cancellation of the employment contract is much more severe than the previously described termination, meaning that the employment relationship is terminated with immediate effect and that the obligations arising from the employment relationship cease to exist as soon as the cancellation comes to the knowledge of the other party. From the employee's perspective, a cancellation is severe because of its rapid effect. Consequently, a cancellation is possible only when the behaviour of the employee has been extremely culpable. The breach of the employment relationship needs to be severe to constitute grounds for cancellation, i.e. so severe that it would be unreasonable to expect the employer to continue the employment relationship. ${ }^{98}$

Cancellation of an employment contract requires that the other party is found to be in breach of the contract in a way that is deemed to be serious. According to

\footnotetext{
96 Aapo, Surakka, Access to Finnish Law (Helsinki: Sanoma Pro, 2012), 197.

97 Because the precondition for the cancellation of an employment contract is that the other party has acted contrary to the contract, the employer is not entitled to cancel the employment contract on production-related or financial grounds. Cf. Ministry of Employment and the Economy, Op.Cit, 46.

98 Government proposal to Parliament "HE 157/2000 vp: Government proposal for the contracts of employment act.",29.
} 
Employment Contracts Act, the employer is entitled to cancel an employment contract with immediate effect, regardless of the applicable period of notice or the duration of the employment contract, only upon an extremely weighty cause. Thus, the employer may only cancel the employment agreement when the conditions for continuing the contract no longer exist because the employee has seriously breached or neglected its duties based on the employment contract or the law.

In addition to the above, according to Employment Contracts Act Chapter 8 Section 3, if the employee has been absent from work for a minimum of seven days without notifying the employer of a valid reason for the absence for this period, the employer is entitled to consider the employment contract cancelled from the date on which the absence began. Likewise, if the employer is absent from the workplace for a minimum of seven days without notifying the employee of a valid reason for this absence, the employee shall be entitled to consider the employment contract cancelled.

Correspondingly, Employment Contract Act (TSL 8:1.2) determines that the employee shall be entitled to terminate the employment contract with immediate effect if the employer commits a breach against or neglects his duties based under on the employment contract or the law and having essential which has such a serious impact on the employment relationship in such a serious manner as to render it unreasonable to expect that the employee should continue the contractual relationship even for the period of notice.

In addition to the above, according to Employment Contracts Act Chapter 8 Section 3, if the employee has been absent from work for a minimum of seven days without notifying the employer of a valid reason for the absence for this period, the employer is entitled to consider the employment contract cancelled from the date on which the absence began. Likewise, if the employer is absent from the workplace for a minimum of seven days without notifying the employee of a valid reason for this absence, the employee shall be entitled to consider the employment contract cancelled.

\subsubsection{Extremely Weighty Causes for Cancellation of an Employment Contract}

Both employment agreements that are valid until further notice and fixedterm employment agreements can be cancelled. According to Employment Contracts Act there must be an extremely weighty reason to cancel an employment contract. However, the Act does not provide a list of the reasons that are adequate for cancellation and because of that, all situations must be solved separately. Instead, the previously enacted Employment Contracts Act (320/1970 and 141/1922) contained an example-list of grounds for cancellation. ${ }^{99}$ Even though the list has been excised, the established

99 Ibid, 29-30. 
legal practice concerning the grounds of cancellation was not meant to be amended and those practices have continued. ${ }^{100}$

The causes for the cancellation are regulated in Chapter 7 of Employment Contracts Act and are closely linked to the grounds for termination of the employment contract. ${ }^{101}$ Both termination and cancellation are based on an overall assessment of the situation. ${ }^{102}$ The grounds for termination and cancellation are similar but there is a gradation between them. ${ }^{103}$ The gradation means that the grounds for a cancellation must be heavier than the grounds which entitle the employer to terminate the employment contract. A similar conduct, but in a slighter form, might entitle the employer to terminate the contract, whereas the more severe behaviour may lead to the cancellation of the employment contract. ${ }^{104}$ In any case, the grounds for the cancellation must always be heavier than the grounds for the termination (cf. the extremely weighty cause and the proper and weighty reason). ${ }^{105}$

As mentioned above, the legally acceptable grounds for the immediate cancellation by the employer must be more persuasive than the legally acceptable grounds for simply giving a notice of the termination. The law expresses the idea as follows; there must be an especially persuasive reason. The reason could be an employee's serious breach or gross negligence of his essential duties under the employment contract or the law. The circumstances must be so drastic that nobody would expect the employer to wait for the end of the notice period. ${ }^{106}$ The established legal practice should be referred to when the grounds for cancellation are being assessed. ${ }^{107}$ When evaluating the boundary between the grounds for the termination and cancellation, the basis is the content and severity of employee's action or omission (a proper and weighty reason - extremely weighty reason). ${ }^{108}$

Labour Court (TT) 2005-44: The employer had cancelled the employment due to employee's neglect of a work obligation. The employer had had a proper and weighty cause to terminate the employment contract but not an extremely weighty cause sufficient to cancel it. Thus, the cancellation of the employment contract was unlawful.

100 Ibid, 109; The Supreme Court of Finland (KKO) 2006:104 paragraphs 5-6; Report of Committee of Employment Contract act” Työsopimuslakikomitean mietintö 2000:1”, 124.

101 Ibid; Harri Hietala, Tapani Kahri and Martti Kairinen, Op.Cit, 480.

102 The Supreme Court of Finland (KKO) 2006:104 paragraph 8.

103 The Supreme Court of Finland (KKO) 2006:104 paragraph 11; The Supreme Court of Finland (KKO) 2012:89: paragraph 10; The Supreme Court of Finland (KKO) 2016:62 paragraph 7.

104 The Supreme Court of Finland (KKO) 2016:62 paragraph 7. Cf. The Supreme Court of Finland KKO:2006:104 paragraph 11.

105 Government proposal to Parliament "HE 157/2000, Ibid, 29.

106 Markus Äimälä and Johan Åström and Mikko Nyyssölä, Op.Cit, 198.

107 Niklas Bruun and Andres von Koskull, Työoikeuden perusteet (Helsinki: Alma Talent Oy, 2012), 112.

108 Jaana Paanetoja, "Työsopimuksen irtisanomis - ja purkamisperusteiden rajankäyntiä". Defensor Legis no. 4 (2014): 521. 
Labour Court (TT) 2013-166: The employee had been working under the influence of alcohol. The employer had the right to terminate (with notice) the employment without giving a warning but no right to cancel it (effective immediately).

\section{Conclusion}

According to Finish Employment Contracts Act, the termination of the employment contract requires a proper and weighty cause whereas the can cellation of the employment contract requires an extremely weighty cause. The meaning of this article was to analyse the grounds and circumstances that may lead to the termination (with notice) or cancellation (with immediate effects) of the employment contract. The grounds for termination and cancellation are similar but there is a gradation between them. That means the grounds for a cancellation must be heavier than the grounds which entitle the employer to terminate the employment contract.

In the legal practice and legal literature, it has been argued that the proper and weighty reason may be for example a neglect of the work obligations, competing activity and violating of the business secrets, use of intoxicants, criminal activity and inappropriate behaviour and in some cases even illness. The final assessment whether the cause is proper and weighty or extremely weighty has to be done by taking the employer's and the employee's overall circumstances into account. When considering the overall circumstances concerning the cause of the termination or cancellation, for example the nature, length and severity of the breach, employee's position and work experience as well as employee's attitude towards the breach, the number of unfulfilled duties in relation to employee's duties, the nature of the work and work circumstances, the nature of the company and normal work practices, along with the position of the employer and the previously received warning must all be taken into account. ${ }^{109}$

Thus, every termination and cancellation of an employment contract is unique; the situations of the terminations and cancellations differ in accordance with the business sector, the individual and the enterprise concerned. For that reason it is not possible to define what is a proper and weighty cause or an extremely weighty cause to either terminate or cancel the employment contract. The grounds for the termination or cancellation can be found from the circumstances of a single case. Hence, a ground that is sufficient in one case may not be sufficient in another case.

109 ICf. Seppo Koskinen and Kimmo Nieminen and Mika Valkonen, Työsuhteen päättäminen (Lithuania: Talentum Media Oy, 2012), 71; Matti-Juhani Moilanen, Sopimukset Työsuhteen Päättyessä (Hämeenlinna: Talentum Media Oy, 2010), 66-67; Kari-Pekka Tiitinen and Tarja Kröger, Op.Cit, 506. 


\section{BIBLIOGRAPHY}

\section{Book}

Bruun, Niklas and von Koskull. Anders: Työoikeuden perusteet. Helsinki: Alma Talent Oy, 2012.

Hietala, Harri, Tapani Kahri, and Martti Kairinen. Työsopimuslaki käytännössä. Helsinki: Alma Talent Oy, 2016.

Hietala, Harri and Keijo Kaivanto. Työsopimus ja johtajasopimus. Helsinki: Alma Talent Oy, 2017.

Kairinen, Martti, et.al. Työoikeus. Juva: WSOYpro, 2006.

Koskinen, Seppo, Kimmo Nieminen, and Mika Valkonen. Työsuhteen päättäminen. Lithuania: Talentum Media Oy, 2012.

Moilanen, Juha-Matti, Sopimukset työsuhteen päättyessä. Hämeenlinna: Talentum Media Oy, 2010.

Surakka, Aapo: Access to Finnish Law. Helsinki: Sanoma Pro, 2012.

Tiitinen, Kari-Pekka and Tanja Kröger. Työsopimusoikeus. Helsinki: Talentum, 2012.

Äimälä, Markus and Kärkkäinen, Mika. Työsopimuslaki. Helsinki: Alma Talent Oy, 2017.

Äimälä, Markus, Johan Åström, Hannu Rautiainen, and Mikko Nyyssölä. Finnish Labour Law in Practice. Helsinki: Alma Talent Oy, 2012.

\section{Journal Article}

Alapuranen, Leena et.al, "Työkyvytön?". Edilex 2008.

Svalund, Jørgen, Antti Saloniemi, and Patrik Vulkan. "Attitudes towards job protection legislation: Comparing insiders and outsiders in Finland, Norway and Sweden.” European Journal of Industrial Relations 22, no. 4 (2016): 371 390. https:/ / doi.org/10.1177/0959680115626057

Furåker, Bengt, Kristine Nergaard, and Antti Saloniemi. "Lock-in patterns among employees: A Nordic comparison." International Journal of Comparative Labour Law and Industrial Relations 30, no. 4 (2014): 435-458. 
Kautonen, Teemu, Simon Down, Friederike Welter, Pekka Vainio, Jenni Palmroos, Kai Althoff, and Susanne Kolb. "Involuntary self-employment" as a public policy issue: a cross-country European review." International Journal of Entrepreneurial Behavior \& Research 16, no. 2 (2010): 112-129. https://doi. org/10.1108/13552551011027002

Koskinen Sandberg, Paula, Maria Törnroos, and Roosa Kohvakka. "The institutionalised undervaluation of women's work: The case of local government sector collective agreements." Work, employment and society (2017): 1-19. https: / / doi.org/10.1177/0950017017711100

Koskinen, Seppo. "Harhaanjohtaminen työsopimusta tehtäessä”, Edilex, (2005): 2-14.

Koskinen, Seppo. "The New Work and New Labour Law-From the Finnish Perspective." Edilex, (2001): 2-103.

Koskinen, Seppo. "Työsuhdeturva". Edilex 2013.

Koskinen, Seppo. "Velvollisuus Antaa Varoitus Työsopimuksen Irtisanomisen Edellytyksenä”. Defensor Legis, No. 6 (2004): 1015-1047.

Mashamba, Clement. "The Promotion of Basic Employee Rights in Tanzania." African Human Rights Law Journal 7, No. 2 (2007): 475-495.

Ollila, Aki. “Työnhakijan tiedonantovelvollisuus”, Defensor Legis, no. 1 (2017): 16-33.

Paanetoja, Jaana. "Työsopimuksen irtisanomis- ja purkamisperusteiden rajankäyntiä", Defensor Legis, no. 4 (2014): 512-534.

Rosin, Annika and Merle Erikson, "A Trainee's Right to a Wage: the Estonian Situation with Comparative Insights from Slovenia, the United States of America and Finland", European Journal of Social Law, no. 3 (2014).

Rosin, Annika, and Merle Muda. "Labour Law Status of a Trainee: The Estonian Situation with Comparative Insights from Finland, France and the US." European Labour Law Journal 4, no. 4 (2013): 292-312. https://doi. org/10.1177/201395251300400404

Sädevirta, Markus. "Regulation of Fixed-Term Employment Contracts in the EU, France, Finland and the United Kingdom: A Comparative Analysis." International Journal of Comparative Labour Law and Industrial Relations 31, no. 2 (2015): 207-231. 


\title{
Thesis or Dissertation
}

Rosin, Annika. "Labour Law Protection of Trainees", Ph.D Thesis, Faculty of Law University of Turku, 2017.

Sandvik, Sebastian. "The Economic and Social Effects of Trial Periods for Employment Contracts," Master Thesis, Faculty of Law University of Helsinki, 2016.

\section{Legal Document}

Työehtosopimuslaki (Collective Agreements Act, 1946/436)

Työsopimuslaki (Employment Contracts Act, 55/2001)

Laki yhteistoiminnasta yrityksissä (Act on Co-operation within Undertakings, 334/2007)

Työterveyshuoltolaki (Occupational Health Act, 2001/1383)

Työturvallisuuslaki (Occupational Safety Act, 738/2002)

\section{Other Document}

Government Proposal to Parliament "HE 157/2000 vp: Government Proposal for the Contracts of Employment Act."

Report of Committee of Employment Contract Act "Työsopimuslakikomitean mietintö 1969:A 25."

Report of Committee of Employment Contract Act "Työsopimuslakikomitean mietintö 2000:1."

Ministry of Employment and the Economy, "Employment Contracts Act. The Position of Employers and Employees under the Employment Contracts Act”, 2014.

\section{Case Law}

\section{The Supreme Court of Finland}

\author{
KKO 1980 II 117 \\ KKO 1983 II 144 \\ KKO 1990:37 \\ KKO 1991:2
}


Udayana Journal of Law and Culture

Vol. 02 No.1, January 2018

KKO 1991:26

KKO 1992:7

KKO 1995:47

KKO 2006:104

KKO 2010:60

KKO 2012:89

KKO 2016:15

KKO 2016:62

\section{The Court of Appeal}

The Court of Appeal of Turku 11.6.2003 S 02/2032

The Court of Appeal of Helsinki 7.1.2004 S 02/2329

The Court of Appeal of Vaasa 24.3.2017 S 16/320

\section{The Labour Court of Finland}

TT 1984-56

TT 1985-62

TT 1992-37

TT 2002-47

TT 2003-97

TT 2004-7

TT 2004-63

TT 2005-1 1

TT 2005-65 